\title{
Korelasi Antara Kecerdasan Emosional dengan Interaksi Sosial Siswa Kelas V SD Gugus VI Pangeran Diponegoro Denpasar Barat
}

\author{
Ni Ketut Agustini ${ }^{1}$, I Wayan Sujana ${ }^{2}$, I Ketut Adnyana Putra ${ }^{3}$ \\ 123 Jurusan PGSD Universitas Pendidikan Ganesha \\ Singaraja, Indonesia \\ e-mail: agustinikt@gmail.com ${ }^{1}$, iwayan.sujana@undiksha.ac.id², \\ ketut.adnyana.putra@undiksha.ac.id ${ }^{3}$
}

\begin{abstract}
Abstrak
Penelitian ini bertujuan untuk mengetahui korelasi yang signifikan antara kecerdasan emosional dengan interaksi sosial siswa kelas V SD Gugus VI Pangeran Diponegoro Denpasar Barat pada tahun pelajaran 2017/2018. Jenis penelitian ini adalah penelitian ex post facto. Populasi dari penelitian ini seluruh siswa kelas V SD yang berada di Gugus VI Pangeran Diponegoro Denpasar Barat Tahun Pelajaran 2017/2018 berjumlah 420 siswa. Penentuan sampel menggunakan teknik proporsional random sampling dengan taraf kesalahan 5\% diperoleh sampel sejumlah 191 siswa. Data kecerdasan emosional dan interaksi sosial diperoleh melalui kuesioner dan pencatatan dokumen. Sebagai uji prasyarat, menggunakan uji normalitas sebaran data. Setelah seluruh uji prasyarat terpenuhi, analisis statistik yang digunakan pada penelitian ini adalah uji hipotesis menggunakan analisis korelasi product moment. Berdasarkan hasil analisis maka diperoleh $r_{x y}$ hitung $=0,430$. Pada Taraf signifikansi $5 \%$ dengan $n=191$, maka diperoleh $r_{x y}$ tabel $=0,138$. Karena $r_{x y}$ hitung $=0,430>r_{x y}$ tabel $=0,138$ maka dapat diartikan bahwa $\mathrm{H}_{0}$ ditolak dan $\mathrm{H}_{\mathrm{a}}$ diterima. Dengan demikian dapat disimpulkan bahwa terdapat korelasi yang signifikan antara kecerdasan emosional dengan interaksi sosial siswa kelas V SD Gugus VI Pangeran Diponegoro Denpasar Barat Tahun Pelajaran 2017/2018 dengan arah korelasi positif yang artinya semakin tinggi kecerdasan emosional semakin meningkat interaksi sosial siswa, serta hasil penelitian ini sebagai pendukung sumber belajar guru dalam meningkatkan kualitas pembelpelajaran dengan membentuk kecerdasan emosional dan interaksi sosial siswa di sekolah sehingga sekolah mampu menghasilkan siswa yang berkualitas.
\end{abstract}

Kata Kunci : Korelasi, Kecerdasan Emosional, Interaksi Sosial

\begin{abstract}
This study was aiming to analyze the correlation that is significant between emotional intelligence with social interaction on $6^{\text {th }}$ grade students at group VI PangeranDiponegoro in West Denpasar in academic year 2017/2018. This study can be categorized as ex post facto research. Population of the students at group VI PangeranDiponegoro in West Denpasar was about 420 students that were being inspected. The sample was being determined using proportional random sampling technique with only 5\% chance of failure and found 191 students were being the sample. The data about emotional intelligence and social interaction was being obtained from questioner and document recording. As prerequisite test, the normality of data distribution test was being used. After each prerequisite test being completed, statistical analysis that is used in the study is hypothesis test using correlation analysis of product moment. Based on the analysis result, then obtained $r_{x y c o u n t}=0,430$. While in chance of failure $5 \%$ with $n=191$, then obtained $r_{x y}$ table $=0,138$. It is because $r_{x y}$ count $=0,430>r_{x y}$ table $=0,138$, it can be interpreted that $H_{0}$ is being rejected and $H_{a}$ is being accepted. Thus, it can be concluded that there is a significant correlation between emotional intelligence with social interaction on $6^{\text {th }}$ grade students at group VI PangeranDiponegoro in West Denpasar in academic year $2017 / 2018$ which is positive correlation that meant the higher emotional intelligence is, the more social interaction is going to be occurred, also the result of this study is being the supportive thing for learning resources for teachers in improving the learning quality by establishing the emotional intelligence and social interaction on students at school thus it can create students that is competent.
\end{abstract}

Keywords: Correlation, Emotional Intelligence, Social Interaction 


\section{Pendahuluan}

Sejalan dengan perkembangan zaman, pembangunan dan teknologi, sebagai usaha peningkatan kualitas sumber daya manusia merupakan hal yang sangat penting. Peningkatan sumber daya manusia yang berkualitas untuk menunjang pembangunan nasional serta mengimbangi kemajuan Ilmu Pengetahuan dan Teknologi (IPTEK) merupakan tugas dari pendidikan. Pemerintah selalu berupaya meningkatkan mutu pendidikan sehingga berbagai inovasi pendidikan telah dilakukan oleh pemerintah sebagai upaya peningkatan mutu pendidikan di Indonesia, baik pada jenjang pendidikan dasar, menengah maupun jenjang pendidikan tinggi. Menurut Undang-Undang Nomor 20 Tahun 2003 tentang Sistem Pendidikan Nasional, Pasal 1 Ayat 1 berbunyi: "pendidikan adalah usaha sadar dan terencana untuk mewujudkan suasana belajar dan proses pembelajaran agar siswa secara aktif mengembangkan potensi dirinya untuk memiliki kekuatan spiritual keagaamaan, pengendalian diri, kepribadian, kecerdasan, akhlak mulia, serta keterampilan yang diperlukan dirinya, masyarakat, bangsa, dan Negara". Dari pernyataan tersebut, terbukti bahwa pendidikan sangat berperan penting dalam kehidupan suatu bangsa, karena pendidikan memiliki pengaruh langsung terhadap perkembangan manusia. Melalui pendidikan diharapkan akan lahir sumber daya manusia yang berkualitas dan dapat membangun kehidupan masyarakat kearah yang lebih baik.

Dalam pendidikan ini akan berlangsung suatu proses antara guru dengan siswa untuk mencapai sebuah tujuan pembelajaran. Berkaitan dengan hal tersebut, dirancanglah sebuah pedoman dalam kegiatan pembelajaran yang disebut dengan kurikulum. Kurikulum terbaru yang digunakan dalam pendidikan di Indonesia adalah Kurikulum 2013. Pandangan ini menjadikan Kurikulum 2013 dikembangkan berdasarkan budaya bangsa Indonesia yang beragam, diarahkan untuk membangun kehidupan masa kini, dan untuk membangun dasar bagi kehidupan yang lebih baik di masa depan.

Mempersiapkan siswa untuk kehidupan masa depan selalu menjadi kepedulian kurikulum, hal ini mengandung makna menurut Undang-Undang Nomor 20 Tahun 2003 tentang Sistem Pendidikan Nasional menyebutkan "kurikulum adalah seperangkat rencana dan pengaturan mengenai tujuan, isi, dan bahan pelajaran serta cara yang digunakan sebagai pedoman penyelenggaraan kegiatan pembelajaran untuk mencapai tujuan pendidikan tertentu". Berdasarkan pengertian tersebut, ada dua dimensi kurikulum, yang pertama adalah rencana dan pengaturan mengenai tujuan, isi, dan bahan pelajaran sedangkan yang kedua adalah cara yang digunakann untuk kegiatan pembelajaran. Dengan demikian tujuan Kurikulum 2013 adalah untuk "mempersiapkan manusia Indonesia agar memiliki kemampuan hidup sebagai pribadi dan warga negara yang beriman, produktif, kreatif, dan afektif serta mampu berkontribusi pada kehidupan bermasyarakat, berbangsa, bernegara, dan peradaban dunia" (Permendikbud Nomor 57 Tahun 2014).

Kurikulum 2013 menganut pandangan dasar bahwa pengetahuan tidak dapat dipindahkan begitu saja dari guru ke siswa. Namun, siswa adalah subjek yang memiliki kemampuan untuk secara aktif mencari, mengolah, mengkonstruksi, dan menggunakan pengetahuannya sebagai proses berlangsungnya pembelajaran. Menurut Permendikbud Nomor 22 Tahun 2016 pada bagian proses pembelajaran menyatakan : "proses pembelajaran pada satuan pendidikan diselenggarakan secara interaktif, inspiratif, menyenangkan, menantang, memotivasi peserta didik untuk berpartisipasi aktif, serta memberikan ruang yang cukup bagi prakarsa, kreativitas, dan kemandirian sesuai dengan bakat, minat, dan perkembangan fisik serta psikologis peserta didik". Setiap satuan pendidikan melakukan perencanaan pembelajaran, pelaksanaan proses pembelajaran serta penilaian proses pembelajaran untuk meningkatkan efisiensi dan efektivitas ketercapaian kompetensi lulusan.

Pembelajaran dalam Kurikulum 2013 menuntut guru agar mampu menjadi faktor kunci untuk mengembangkan potensi dan karakter siswa. Karakter siswa berkembang berdasarkan potensi yang dibawa sejak lahir atau yang dikenal sebagai karakter dasar yang bersifat biologis. Karakter adalah keseluruhan nilai-nilai, pemikiran, perkataan, perilaku atau perbuatan yang telah membentuk diri seseorang. Dengan demikian, karakter dapat disebut sebagai jati diri seseorang yang telah terbentuk dalam proses kehidupan yang berupa pola pikir, sikap dan perilaku. Karakter dapat dibentuk melalui pendidikan, karena pendidikan karakter adalah "usaha yang sungguh-sungguh untuk memahami, membentuk, memupuk nilai-nilai etika, baik untuk diri sendiri maupun untuk semua warga masyarakat atau warga negara secara keseluruhan" (Zubaedi, 2011:19). 
Dalam pendidikan karakter, guru berperan penting mengembangkan karakter siswa dengan upaya membantu siswa untuk memahami, peduli, dan berbuat atau bertindak berdasarkan nilai-nilai dan etika. Pendidikan karakter pada hakekatnya merupakan pengintegrasian antara kecerdasan, kepribadian, dan akhlak mulia. Dengan pendidikan karakter yang diterapkan secara sistematis dan berkelanjutan, seorang siswa akan menjadi cerdas emosinya dalam mepertajam dan memperkuat perasaan moralnya, sehingga ia akan mampu bertindak dengan benar. Kecerdasan emosional adalah bekal terpenting dalam mempersiapkan siswa menyongsong masa depan, karena dengan kecerdasan emosional siswa akan dapat berhasil dalam menghadapi segala macam tantangan, termasuk tantangan untuk berhasil secara akademis. Menurut Daniel Golmen (1999:512) pengarang buku Emotional Intelligence pada bagian buku yang diberi judul Working with Emotional Intelligence menjelaskan bahwa kecerdasan emosi atau emotional intellegence merujuk kepada "kemampuan mengenali perasaan diri sendiri, dan perasaan orang lain, kemampuan memotivasi diri sendiri, dan kemampuan mengelola emosi dengan baik pada diri sendiri dan dalam hubungan dengan orang lain".

Dilihat dari karakter siswa sekolah dasar pada masa kini kecerdasan emosional perlu dikembangkan pada diri siswa, karena tidak jarang dijumpai siswa yang begitu cemerlang prestasi akademiknya namun tidak dapat mengelola emosinya, seperti mudah marah, angkuh dan sombong. Kurangnya pemahaman siswa terhadap kecerdasan emosional pada dirinya, membuat siswa tidak mampu mengendalikan emosinya dan menyesuaikan dirinya dengan situasi atau masalah yang sedang dihadapi. Siswa yang sulit mengelola emosinya sendiri dapat dipastikan tidak akan mampu menghormati perasaan orang lain dan berhubungan baik dengan orang lain. Dalam dunia pendidikan, gurulah yang berperan penting dalam mengembangkan kecerdasan emosional siswa secara optimal sehingga siswa cenderung memiliki kecerdasan emosional yang positif. Menurut Maksum (2013:Vol.03) "mendidik seseorang untuk bisa menjadi pintar mungkin terlalu mudah dan bisa dilakukan oleh siapapun, akan tetapi mendidik seseorang untuk memiliki emosi yang baik dengan cara mewujudkan suasana pembelajaran yang menyenangkan tanpa ada perasaan tertekan, tidak semua orang bisa melakukannya". Kecerdasan emosional sangat dipengaruhi oleh lingkungan, tidak bersifat menetap, dapat berubah-ubah setiap saat. Untuk itu "peranan lingkungan terutama orang tua pada masa kanakkanak sangat mempengaruhi dalam pembentukan kecerdasan emosional" (Elmia Umar, 2014:Vol.1).

Menurut Sari (2015) Kecerdasan emosi sebagai faktor yang menentukan pemahaman individu terhadap dirinya sendiri maupun terhadap orang lain akan mempengaruhi per- ilaku individu dalam hubungan dengan orang lain, individu yang dapat memahami dirinya sendiri dan orang lain secara utuh dan men- dalam akan memandang dan menilai segala sesuatu secara positif dan begitu juga seba- liknya. Menurut Murni (2015) Kecerdasan emosional perlu dikembangkan pada diri siswa, karena tidak jarang dijumpai siswa yang begitu cemerlang prestasi akademiknya, namun tidak dapat mengelola emosinya, seperti mudah marah, angkuh dan sombong. Siswa yang sulit mengelola emosinya sendiri, dapat dipastikan tidak akan mampu menghormati perasaan orang lain, berhubungan yang baik dengan orang lain, kurang memiliki sifat ulet dan kurang bijaksana. Menurut Fitriyani (2015) kecerdasan emosi adalah suatu jenis kecerdasan yang dimiliki oleh seseorang yang mengacu pada pemusatan perhatian dalam mengenali, memahami, merasakan, mengelola, memotivasi diri sendiri dan orang lain serta dapat mengaplikasikan kemampuan tersebut dalam kehidupan pribadi dan sosial. Kecerdasan emosional sangat mempengaruhi adanya interaksi sosial. Dimana berdasarkan penjelasan diatas bahwa kecerdasan emosional itu merujuk pada kemampuan mengelola emosi dengan baik pada diri sendiri dan dalam hubungan dengan orang lain. Sehingga kemampuan mengelola emosi dalam hubungan dengan orang lain akan mempengaruhi adanya interaksi sosial. Menurut Sujarwanto (2012) proses interaksi sosial akan akan menghasilkan dua bentuk, yaitu proses asiosiatif dan disosiatif. Bentuk interaksi sosial asosiatif merupakan bentuk interaksi yang mengarah pada keharmonisan, keintiman hubungan sedangan bentuk proses disosiatif mengarah pada ketidak harmonisan bahkan sampai pada perpecahan. Bentuk interaksi sosial yang berupa proses asosiatif meliputi: Kerja sama (Cooperation), akomodasi dan Asimilasi. Kerjasama merupakan bentuk interaksi sosial yang pokok. Menurut Fatnar (2014) kemampuan interaksi sosial merupakan kesanggupan individu untuk saling berhubungan dan bekerja sama dengan individu lain maupun kelompok di mana kelakuan individu yang satu dapat mempengaruhi, mengubah, atau memperbaiki kelakuan individu lain atau sebaliknya, sehingga terdapat adanya hubungan yang saling timbal balik. Menurut Maryati \& Suryawati (2001:56) interaksi sosial adalah "hubungan timbal balik (sosial) berupa aksi saling 
mempengaruhi antara individu dan individu, antara individu dan kelompok, dan antara kelompok dan kelompok".

Dalam pemenuhan kebutuhan hidupnya, siswa tidak lepas dari berhubungan sosial dengan orang lain. Hal ini karena setiap hari siswa melakukan interaksi dengan individu baik secara langsung atau tatap muka maupun secara tidak langsung. Siswa dalam berinteraksi sosial dapat dikategorikan ke dalam dua kelompok yaitu siswa yang dapat dikategorikan sebagai siswa yang bisa berinteraksi sosial dengan baik atau pandai bergaul dan sebaliknya yaitu siswa yang mengalami kesulitan bergaul atau individu yang tidak bisa berinteraksi sosial dengan baik. Siswa yang berinteraksi sosial dengan baik biasanya dapat mengatasi berbagai persoalan didalam pergaulan. Mereka tidak mengalami kesulitan untuk menjalani hubungan dengan teman baru, berkomunikasi secara efektif dengan orang lain, terlibat dalam pembicaraan yang menyenangkan, dan dapat mengakhiri pembicaraan tanpa mengecewakan atau menyakiti orang lain. Sebaliknya siswa yang tidak bisa berinteraksi dengan baik merasa kesulitan dalam berkomunikasi, merasa rendah diri, merasa takut untuk mengeluarkan pendapat sehingga siswa yang demikian lebih memilih diam dan menyendiri. Dengan keadaan yang demikian akan menimbulkan suatu permasalahan terutama dalam masalah interaksi sosial sehingga perlu penanganan lebih cepat agar permasalahan tersebut tidak berlarut-larut sampai siswa tesebut melanjutkan pendidikan yang lebih tinggi.

Berdasarkan hasil observasi yang telah dilakukan maka ditemukan permasalahan yang ada disekolah dasar pada umumnya yaitu kurangnya pemahaman siswa terhadap kecerdasan emosional pada dirinya sehingga siswa perlu mengembangkan dan membentuk kecerdasan emosionalnya secara optimal. Pada masa kini kecerdasan emosional yang dimiliki siswa masih lemah, dimana dilihat dari siswa masa kini lebih cenderung pesimis, takut dan memiliki rasa benci dalam berhubungan sosial dengan orang lain. Sehingga dengan demikian tentunya membuat siswa sulit memantau, membimbing perasaan, pikiran dan tindakan dalam berhubungan atau berinteraksi sosial dengan orang lain. Pada dasarnya setiap siswa memiliki sikap dan karakter tersendiri, tetapi jika guru atau orang tua membentuk kecerdasan emosional siswa melalui kegiatan positif, maka sangat membantu siswa dalam mengembangkan kecerdasan emosionalnya dan membuat siswa mampu menyesuaikan dirinya dengan situasi atau masalah yang sedang dihadapi.

Berdasarkan uraian tersebut salah satu yang menunjang kecerdasan emosional sangat erat kaitannya dengan interaksi sosial. Karena kecerdasan emosional membuat siswa mampu merasakan, memahami, menghargai orang lain dan secara selektif menerapkan daya dan kepekaan emosi sebagai sumber energi melakukan interaksi sosial. Dengan demikian penelitian ini dilakukan untuk mengetahui apakah kecerdasan emosional berhubungan secara signifikan dengan interaksi sosial, maka akan dilakukan penelitian dengan judul "Korelasi Antara Kecerdasan Emosional Dengan Interaksi Sosial Siswa Kelas V SD Gugus VI Pangeran Diponegoro Denpasar Barat Tahun Pelajaran 2017/2018".

\section{Metode}

Penelitian ini merupakan penelitian Ex Post Facto Korelasional karena penelitan ini bertujuan untuk mengetaui koreasi antara kecerdasan emosional dengan interaksi sosial siswa, dengan tidak memanipulasi variabel bebas atau menggali fakta yag sudah terjadi sebelumnya. Populasi dalam penelitian ini adalah siswa kelas V SD Gugus VI Pangeran Diponegoro Denpasar Barat tahun pelajaran 2017/2018 yang berjumlah 420 siswa.

Berdasarkan tabel Issac and Michael, jumlah populasi yan terdapat di Gugus VI Pangeran Diponegoro Denpasar Barat adalah 420 orang siswa dan jumlah sampel yang diambil berdasarkan tingkat kesalahan $5 \%$ berjumlah 191 orang siswa. Pengambilan sampel dalam penelitian ini menggunakan teknik proporsional random sampling yang artirnya teknik pengambilan sampel secara acak dengan memperhatikan jumlah siswa dari masing-masing kelas sesuai dengan proporsi yang terdapat didalam populasi tersebut.

Metode yang digunakan dalam pengumpulan data adalah metode teknik non tes, jenis tekik non tes yang digunakan dalam penelitian ini yaitu kuesioner dan pencatatan dokumen. Dalam penelitian ini sesuai dengan data yang dikumpulkan, instrumen yang digunakan adalah kuesioner kecerdasan emosional dan interaksi sosial. Sedangkan pencatatan dokumen hanya untuk mencari absensi siswa kelas V SD Gugus VI Pangeran Diponegoro Denpasar Barat Tahun Pelajaran 2017/2018.

Kuesioner kecerdasan emosional dan interaksi sosial dibuat sendiri berdasarkan pembahasan dikajian teori yang digunakan sebagai pedoman indikator. Indikator kecerdasan 
emosional terdiri dari mengenali dan memahami emosi diri sendiri, memahami penyebab timbulnya emosi, mengendalikan emosi, mengekspresikan emosi dengan tepat, optimis, dorongan berprestasi, peka terhadap perasaan orang lain, dapat bekerja sama, dapat berkomunikasi. Sedangkan indikator interaksi sosial terdiri dari menerima masukan dari guru, menerima masukan dari teman, menjalin hubungan dengan guru, menjalin hubungan dengan teman, dapat menyampaikan pendapat secara lisan dalam diskusi kelas, berbicara didepan orang banyak, berkomunikasi dengan guru, berkomunikasi dengan teman. Kedua kuesioner tersebut sebagai alat ukur untuk mengetahui sejauh mana kecerdasan emosional dan interaksi sosial yang dimiliki oleh siswa kelas V SD Gugus VI Pangeran Diponegoro Denpasar Barat. Jumlah masing-masing item kuesioner yaitu 25 pernyataan. Pengujian instrumen dalam penelitian ini menggunakan validitas logis dan validitas empiris. Cara pemberian skor pada kuesioner kecerdasan emosional dan kuesioner interaksi sosial yaitu menggunakan skala likert.

Pencatatan dokumen yang digunakan untuk pengumpulan data siswa kelas V SD Gugus VI Pangeran Diponegoro Denpasar Barat tahun pelajaran 2017/2018 diperoleh dari data absensi siswa.

Analisis dalam penelitian ini menggunakan analisis statistik inferensial. Teknik analisis data yang digunakan teknik korelasi product moment yang digunakan unuk mencari hubungan dua variabel yaitu variabel bebas dan variabel terikat dengan menggunakan data interval atau ratio. Untuk memenuhi persyaratan uji hipotesis maka diperlukan uji persyaratan analisis yaitu uji normalitas dan uji hipotesis statistik.

Uji normalitas digunakan untuk menguji apakah data variabel bebas dan variabel terikat berdistribusi normal atau tidak, dengan cara menggunakan rumus chi-kuadrat dengan kriteria yang digunakan adalah dengan membandingkan nilai $x^{2}$ tabel dengan $x^{2}$ hitung pada taraf signifikansi $5 \%$ dengan ketentuan $x^{2}{ }_{\text {hitung }}<x^{2}$ tabel maka data berdistribusi normal.

Uji hipotesis statistik menggunakan korelasi product moment dengan mengetes antara variabel bebas $(X)$ dan variabel terikat $(Y)$. Hipotesis yang diuji dalam penelitian ini adalah $\mathrm{H}_{\circ}$ yang berbunyi tidak terdapat korelasi yang signifikan antara kecerdasan emosional dengan interaksi sosial siswa kelas V SD Gugus VI Pangeran Diponegoro Denpasar Barat tahun pelajaran 2017/2018. Kriteria yang digunakan dalam pengujian korelasi product moment ini yaitu dengan menggunakan taraf signifikansi $5 \%$. Adapun ketentuan yang diuji dalam penelitian ini jika $r_{x y}$ hitung $>r_{x y}$ tabel maka $H_{0}$ ditolak berarti ada korelasi antara kecerdasan emosional $(X)$ dengan interaksi sosial $(Y)$ sebaliknya jika $r_{x y}$ hitung $<r_{x y}$ tabel maka $H_{0}$ diterima berarti tidak ada korelasi antara kecerdasan emosional $(\mathrm{X})$ dengan interaksi sosial $(\mathrm{Y})$.

\section{Hasil dan Pembahasan}

\section{Deskripsi Data Kecerdasan Emosional}

Data mengenai kecerdasan emosional siswa kelas V SD Gugus VI Pangeran Diponegoro Denpasar Barat diperoleh melalui penyebaran kuesioner. Sampel yang dibagikan kuesioner berjumlah 191 responden dan diberikan 25 butir pernyataan. Data nilai kuesioner kecerdasan emosional dapat dilihat sebagai beirkut:

Tabel 1. Data Nilai Kuesioner Kecerdasan Emosional Siswa

\begin{tabular}{lcc}
\hline & Data Statistik & Nilai \\
\hline Mean & 80,54 \\
Skor Maksimum & 93 \\
Skor Minimum & 65 \\
\hline
\end{tabular}

Berdasarkan data nilai kuesioner kecerdasan emosional rata-rata siswa kelas V SD Gugus VI Pangeran Diponegoro Tahun Pelajaran 2017/2018 mendapatkan nilai 80,54. Nilai kecerdasan emosional siswa yang tertinggi 93 dan yang terendah 65. Dari data di atas dapat juga dilihat dalam bentuk grafik, sehingga dapat dilihat sebagai berikut : 


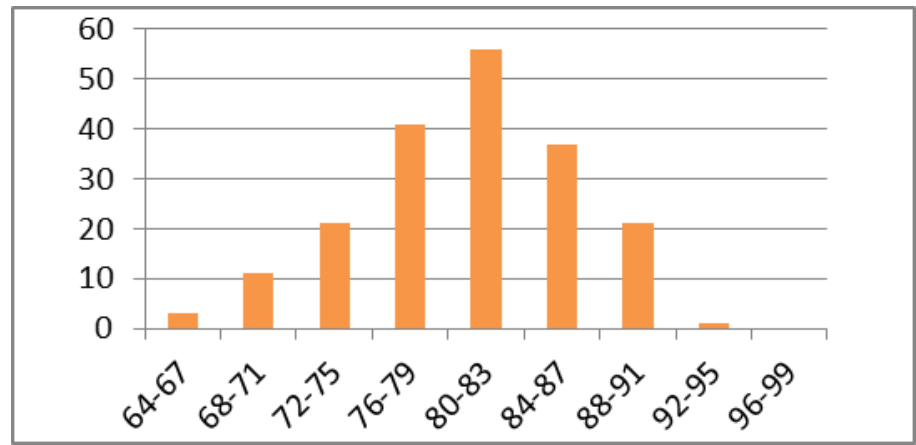

Gambar 1. Histogram Data Kecerdasan Emosional

Berdasarkan histogram tentang data kecerdasan emosional dapat diketahui bahwa frekuensi nilai terbanyak terdapat pada kelas interval ke-5, selanjutnya dapat dilihat data berikut ini tentang tingkat kategori kecerdasan emosional siswa kelas V SD Gugus VI Pangeran Diponegoro Denpasar Barat Tahun Pelajaran 2017/2018.

Tabel 2. Pedoman Konversi PAP Skala Lima Kecerdasan Emosional

\begin{tabular}{cc}
\hline Persentase Kecerdasan Emosional & Kriteria Kecerdasan Emosional \\
\hline $90-100$ & Sangat Tinggi \\
$80-89$ & Tinggi \\
$65-79$ & Sedang \\
$55-64$ & Rendah \\
$0-54$ & Sangat Rendah \\
\hline
\end{tabular}

(Sumber:Agung,2014)

Berdasarkan kategori kecerdasan emosional diatas serta hasil analisis data, bahwa rerata dari kecerdasan emosional siswa kelas V Gugus VI Pangeran Diponegoro Denpasar Barat adalah 80,54. Berdasarkan data tersebut maka dapat disimpulkan bahwa nilai kecerdasan emosional siswa kelas V SD Gugus VI Pangeran Diponegoro Denpasar Barat, tergolong kategori tinggi.

Deskripsi Data Interaksi Sosial

Data mengenai interaksi sosial siswa kelas V SD Gugus VI Pangeran Diponegoro Denpasar Barat diperoleh melalui penyebaran kuesioner. Sampel yang dibagikan kuesioner berjumlah 191 responden dan diberikan 25 butir pernyataan. Data nilai kuesioner interaksi sosial dapat dilihat sebagai beirkut:

Tabel 3. Data Nilai Interaksi Sosial Siswa

\begin{tabular}{lcc}
\hline & Data Statistik & Nilai \\
\hline Mean & 81,79 \\
Skor Maksimum & 97 \\
Skor Minimum & 66 \\
\hline
\end{tabular}

Berdasarkan data nilai interaksi sosial rata-rata siswa kelas V SD Gugus VI Pangeran Diponegoro Tahun Pelajaran 2017/2018 mendapatkan nilai 81,91. Nilai interaksi sosial siswa yang tertinggi 97 dan yang terendah 66. Dari data di atas dapat juga dilihat dalam bentuk grafik, sehingga dapat dilihat sebagai berikut: 


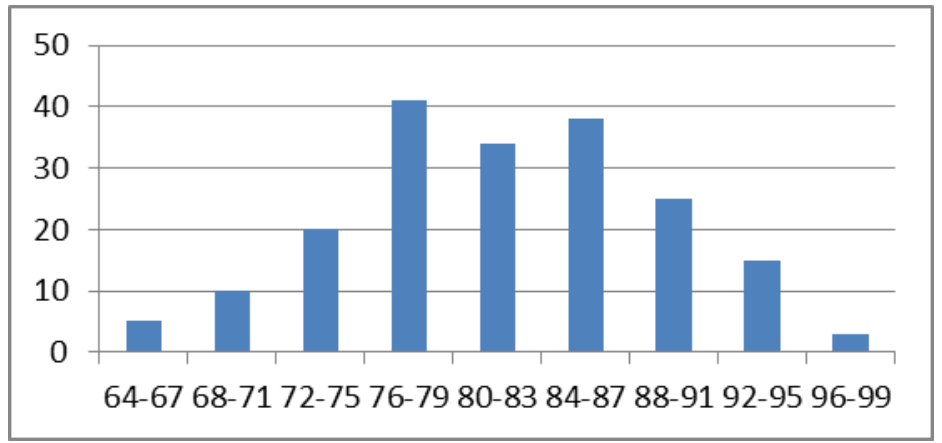

Gambar 2. Histogram Data Interaksi Sosial

Berdasarkan histogram tentang data interaksi sosial dapat diketahui bahwa frekuensi nilai terbanyak terdapat pada kelas interval ke-4, selanjutnya dapat dilihat data berikut ini tentang tingkat kategori interaksi sosial siswa kelas V SD Gugus VI Pangeran Diponegoro Denpasar Barat Tahun Pelajaran 2017/2018.

Tabel 4. Pedoman Konversi PAP Skala Lima Interaksi Sosial

\begin{tabular}{cc}
\hline Persentase Interaksi Sosial & Kriteria InteraksiSosial \\
\hline $90-100$ & Sangat Baik \\
$80-89$ & Baik \\
$65-79$ & Cukup \\
$55-64$ & Kurang \\
$0-54$ & Sangat Kurang \\
\hline
\end{tabular}

(Sumber:Agung,2014)

Uji Prasyarat Analisis

Uji normalitas kecerdasan emosional $(X)$ dan interaksi sosial $(Y)$ menggunakan teknik uji Chi-Kuadrat $\left(\mathrm{x}^{2}\right)$.Nilai dari variabel $\mathrm{X}$ dan $\mathrm{Y}$ dapat dikatakan berdistribusi normal apabila $\mathrm{x}^{2}$ hitung $<$ $\mathrm{x}^{2}$ tabel.

Hasil uji normalitas kecerdasan emosional $(X)$ yaitu $x^{2}{ }_{\text {hitung }}=9,45$. Berdasarkan analisis maka diperoleh $\mathrm{x}^{2}$ hitung $=9,45$ dan menggunakan taraf signifikansi $5 \%$ dengan menggunakan derajat kebebasan 5, maka diperoleh $x^{2}$ tabel $=11,07$. Hal ini berati $x^{2}$ hitung $9,45<x^{2}$ tabel 11,07 maka dapat dinyatakan sebaran data berdistribusi normal. Sedangkan hasil uji normalitas interaksi sosial $(Y)$ yaitu $x^{2}{ }_{\text {ittung }}=5,94$. Berdasarkan analisis maka diperoleh $x^{2}$ hitung $=5,94$ dan menggunakan taraf signifikansi $5 \%$ dengan menggunakan derajat kebebasan 5 , maka diperoleh $x_{\text {tabel }}^{2}=11,07$. Hal ini berati $x^{2}$ hitung $5,94<x^{2}$ tabel 11,07 maka dapat dinyatakan sebaran data berdistribusi normal. Hasil tersebut membuktikan bahwa data kedua variabel bebas dan terikat bersifat normal.

\section{Pengujian Hipotesis}

Setelah dilakukan uji prasyarat dan diketahui data berdistribusi normal, dilanjutkan uji hipotesis guna mengetahui adanya korelasi antar variabel. Uji hipotesis yang dilakukan adalah uji hipotesis dengan menggunakan teknik analisis product moment (variabel $\mathrm{X}$ dengan variabel Y), maka untuk tujuan analisis data dirumuskan dalam hipotesis nol $\left(\mathrm{H}_{0}\right)$. Hipotesis yang dirumuskan yaitu $\mathrm{H}_{0}$ : Tidak terdapat korelasi yang signifkan antara kecerdasan emosional dengan interaksi sosial siswa kelas V SD Gugus VI Pangeran Diponegoro Denpasar Barat Tahun Pelajaran 2017/2018.

Berdasarkan tabel penolong untuk mencari nilai $r$ dengan menggunakan rumus product moment dan dibantu menggunakan Microsoft excel 2010. Pengujian koefisien korelasi dengan rumus product moment diperoleh hasil $r_{x y}$ hitung $=0,430$. Untuk uji koefisien korelasi, digunakan nilai tabel product moment $(r)$ untuk $n=191$, pada taraf signifikansi $5 \%$ diperoleh hasil adalah 0,138 . Maka dapat dinyatakan $r_{x y}$ hitung $>r_{x y}$ tabel. Ini berarti nilai $r_{x y}$ hitung signifikan dengan nilai 0,430 sehingga $H_{0}$ yang berbunyi tidak terdapat korelasi yang signifikan antara kecerdasan 
emosional dengan interaksi sosial siswa kelas V SD Gugus VI Pangeran Diponegoro Denpasar Barat Tahun Pelajaran 2017/2018 ditolak dan $\mathrm{H}_{\mathrm{a}}$ diterima.

Berdasarkan hasil perhitungan $r_{x y}$ hitung dengan membandingkan $r_{x y}$ tabel dilihat dari hasilnya hal ini menunjukan bahwa terjadi korelasi, antara kecerdasan emosional dengan interaksi sosial. Sedangkan arah korelasi, dari hasil penelitian ini yaitu arah korelasi positif berarti semakin tinggi kecerdasan emosional yang dimiliki siswa semakin meningkat interaksi sosial siswa.

Berdasarkan hasil penelitian yang telah dilakukan mengenai korelasi antara kecerdasan emosional dengan interaksi sosial siswa kelas V SD Gugus VI Pangeran Diponegoro tahun pelajaran 2017/2018, uraian yang telah dipaparkan dapat dikemukakan interprestasi, maka hal ini membuktikan bahwa rata-rata siswa kelas V SD di Gugus VI Pangeran Diponegoro tergolong memiliki kecerdasan emosional tinggi dan interaksi sosial yang tinggi, hal ini berarti jika siswa memiliki kecerdasan emosional rendah maka rendah pula interaksi sosial siswa. Berdasarkan hal tersebut, tingginya kecerdasan emosional yang dimiliki siswa dalam berinteraksi sosial memiliki pengaruh yang baik terhadap siswa karena apabila siswa yang memiliki kecerdasan emosional tinggi ia akan mampu berinteraksi sosial dengan baik sehingga secara garis besar siswa yang berinteraksi sosial dengan baik biasanya dapat mengatasi berbagai persoalan dalam pergaulan, tidak mengalami kesulitan untuk menjalani hubungan dengan teman baru, berkomunikasi secara efektif dengan orang lain, dan dapat mengakhiri pembicaraan tanpa mengecewakan atau menyakiti orang lain. Interaksi sosial sangat erat kaitannya dengan kecerdasan emosional karena kecerdasan emosional membuat siswa mampu merasakan, memahami, menghargai orang lain, dan secara selektif menerapkan daya dan kepekaan emosi sebagai sumber melakukan interaksi sosial.

Kecerdasan emosional sangat mempengaruhi adanya interaksi sosial karena kecerdasan emosioal merujuk pada kemampuan mengenali emosi orang lain dan kemampuan membina hubungan sosial dengan orang lain sehingga kemampuan mengenali emosi orang lain dalam berhubungan sosial akan mempengaruhi adanya interaksi sosial. Hal ini diungkapkan juga menurut Umi Ardiaingsih,dkk (2003) mengatakan bahwa kemampuan untuk mengenali emosi orang lain disebut juga empati dan kemampuan membina hubungan dengan orang lain adalah keterampilan-keterampilan seseorang untuk berhubungan dengan orang lain yang merupakan kecakapan emosional yang mendukung keberhasilan dalam bergaul dengan orang lain.

Kecerdasan emosional yang dimiliki siswa bermacam-macam dan berbeda antara siswa satu dengan siswa yang lain dimana apabila seorang siswa mempunyai kecerdasan emosional yang tinggi akan lebih mudah berinteraksi sosial dengan orang lain sehingga siswa cenderung mampu menyesuaikan dirinya dengan situasi atau masalah yang sedang dihadapi. Tetapi apabila seorang siswa mempunyai kecerdasan emosional rendah akan sulit berinteraksi sosial dengan baik karena siswa tidak akan mampu mengetahui perasaannya sendiri sehingga siswa akan sering menyalahkan orang lain dan juga siswa akan sulit menyesuaikan dirinya dengan lingkungannya.

Kecerdasan emosional siswa perlu dikembangkan dan dibentuk sejak dini. Dimana seseorang yang berpengaruh terhadap pembentukan kecerdasan emosional dalam kehidupan siswa yaitu orang tua dan guru. Orang tua adalah subjek pertama yang perilakunya diidentifikasi oleh anak sehingga dengan demikian kepribadian orang tua baik yang menyangkut sikap, kebiasaan berperilaku atau tata bicara hidupnya merupakan unsur-unsur pendidikan yang tidak langsung memberikan pengaruh terhadap perkembangan anak. Kemudian guru juga mempunyai pengaruh besar terhadap pembentukan kecerdasan emosional siswa, dimana guru memegang peranan penting dalam mengembangkan kecerdasan emosional siswa seperti guru dapat mengarahkan siswa melakukan kegiatan yang positif sehingga kecerdasan emosional siswa dapat berkembang secara optimal.

Dalam penelitian ini untuk uji koefisien korelasi, digunakan nilai tabel product moment $(r)$ untuk $\mathrm{n}=191$, pada taraf signifikansi $5 \%$ diperoleh angka sebesar 0,138 . Maka dapat dinyatakan $r_{x y}$ hitung $>r_{x y}$ tabel. Ini berarti $r_{\text {hitung }}$ signifikan dengan nilai 0,430 sehingga $H_{0}$ yang berbunyi tidak terdapat korelasi yang signifikan antara kecerdasan emosional dengan interaksi sosial siswa kelas V SD Gugus VI Pangeran Diponegoro Denpasar Barat Tahun Pelajaran 2017/2018 ditolak dan $\mathrm{H}_{\mathrm{a}}$ diterima. Hal ini sejalan dengan penelitian yang dilakukan oleh $\mathrm{M}$. Asrori dkk (2014) dengan nilai $r_{\text {hitung }}=0,334$ pada nilai $r_{\text {tabel }}=0,266$ yang mempunyai arti bahwa didapatkan korelasi positif signifikan antara kecerdasan emosional dengan interaksi sosial siswa kelas VII MTs Negeri 2 Pontianak. Berarti semakin baik kecerdasan emosional siswa, semakin baik pula interaksi sosial siswa kelas VII MTs Negeri 2 Pontianak. 


\section{Simpulan dan Saran}

Berdasarkan hasil analisis dengan menggunakan Microsoft excel 2010 dan menghitung manual. Nilai tabel poduct moment $(r)$ untuk $n=191$, pada taraf signifikansi $5 \%$ diperoleh

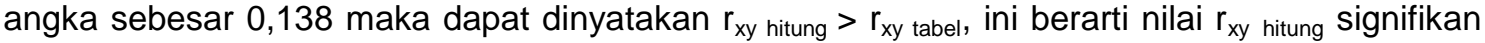
dengan nilai 0,430 sehingga $\mathrm{H}_{0}$ yang berbunyi tidak terdapat korelasi yang signifikan antara kecerdasan emosional dengan interaksi sosial siswa kelas V SD Gugus VI Pangeran Diponegoro Denpasar Barat Tahun Pelajaran 2017/2018 ditolak dan $\mathrm{H}_{\mathrm{a}}$ diterima.

Hasil analisis menunjukan bahwa terdapat korelasi yang signifikan antara kecerdasan emosional dengan interaksi sosial siswa kelas V SD Gugus VI Pangeran Diponegoro Denpasar Barat Tahun Pelajaran 2017/2018. Dengan memiliki arah korelasi yang positif karena nilai $r$ positif, berarti semakin tinggi kecerdasan emosional semakin meningkatnya interaksi sosial siswa.

Berdasarkan uraian tersebut kita mengemukakan interprestasi, maka ini berarti bahwa rata-rata siswa yang tergolong memiliki kecerdasan emosional dengan kategori tinggi dan memperoleh interaksi sosial yang tinggi pula dibandingkan siswa yang memiliki kecerdasan emosional rendah tentu mendapatkan nilai interaksi sosial rendah pula. Jadi dapat disimpulkan bahwa korelasi antara kecerdasan emosional dengan interaksi sosial memiliki korelasi dengan arah korelasi positif.

Adapun saran yang dapat disampaikan berdasarkan hasil penelitian ini adalah (1) kepada siswa, berdasarkan temuan penelitian yang diperoleh, disarankan kepada siswa untuk menumbuhkan kecerdasan emosional dan interaksi sosial siswa, sehingga siswa dapat mengelola, mengontrol, dan mengkoordinasikan keadaan emosi secara optimal dilingkungan sekitar. (2) kepada guru, berdasarkan temuan penelitian yang diperoleh, disarankan kepada guru agar lebih menumbuhkan dan membentuk kecerdasan emosional secara optimal pada siswa sejak dini dalam proses interaksi sosial disekolah. (3) kepada sekolah, berdasarkan temuan penelitian, disarankan kepada kepala sekolah agar dapat menggunakan hasil penelitian ini sebagai pendukung sumber belajar guru dalam meningkatkan kualitas pembelajaran dengan membentuk dan menumbuhkan kecerdasan emosional dan interaksi sosial siswa di sekolah sehingga sekolah mampu menghasilkan siswa yang berkualitas. (4) kepada peneliti lain, berdasarkan temuan penelitian, disarankan kepada peneliti agar hasil penelitian ini digunakan sebagai referensi untuk melaksanakan penelitian selanjutnya dan semoga penelitian ini bermanfaat bagi seluruh masyarakat yang menggunakan penelitian ini.

\section{Daftar Rujukan}

Fatnar, Virgia Ningrum, dan Choirul Anam. 2014. Kemampuan Interaksi Sosial antara Remaja yang Tinggal di Pondok Pesantren dengan yang Tinggal Bersama Keluarga. Jurnal $\begin{array}{lllll}\text { Fakultas Psikologi } \quad \text { Vol. } & \text { No 2, Hal. }\end{array}$ http://journal.uad.ac.id/index.php/EMPATHY/. Diakses 27 Mei 2019.

Fitriyani, Listia. 2015. Peran Pola Asuh Orang Tua Dalam Mengembangkan Kecerdasan Emosi Anak. Lentera, Vol. XVIII No. 1 Hal. 93-110. https://journal.iainsamarinda.ac.id/index.php/lentera_journal/ . Diakses 27 Mei 2019.

Golmen, Daniel. 1995. Emotional Itelligence (Kecerdasan Emosional). Jakarta: PT Gramedia Pustaka Utama.

Golmen, Daniel. 1999. Kecerdasan Emosi Untuk Mencapai Puncak Pretasi. Jakarta: Gramedia Pustaka Utama.

Maksum, Khanif. 2013. Hubungan Kecerdasan Emosional Dan Motivasi Dengan Tingkat Prestasi Belajar Siswa Kelas V Madrasah Ibtidaiyah Negeri (MIN) Jajaran Bantul Pada Mata Pelajaran Bahasa Indonesia. Vol.03.Nomor.01. di akses tanggal: 28 Desember 2017.

Murni, M. Asrori, Indri Astuti. 2015. Korelasi Kecerdasan Emosional Dengan Interaksi Sosial Siswa Kelas VII MTs Negeri 2 Pontianak. Jurnal Pendidikan dan Pembelajaran Vol. 4 No. 9 Hal. 1-13. http://jurnal.untan.ac.id/index.php/jpdpb/issue/view/506. Diakses 27 Mei 2019. 
Permendikbud. 2014. Peraturan Menteri Pendidikan dan Kebudayaan Republik Indonesia Nomor 57 Tahun 2014 Tentang Kurikulum 2013 Sekolah Dasar/ Madrasah Ibtidaiyah. Jakarta: Kementrian Pendidikan dan Kebudayaan.

Permendikbud. 2016. Peraturan Menteri Pendidikan dan Kebudayaan Republik Indonesia Nomor 22 Tahun 2016 Tentang Standar Proses Pendidikan Dasar dan Menengah. Jakarta: Kementerian Pendidikan dan Kebudayaan. di akses tanggal: 22 Oktober 2016.

Sari, Teti Devita, dan Ami Widyastuti. 2015. Hubungan Antara Kecerdasan Emosi dengan Kemampuan Manajemen Konflik Pada Istri. Jurnal Psikologi Vol. 11 No. 1 Hal. 49-54. http://ejournal.uin-suska.ac.id/index.php/psikologi/. Diases 27 Mei 2019.

Sujarwanto, Imam. 2012. Interaksi Sosial antar Umat Beragama (Studi Kasus pada Masyarakat Karangmalang Kedungbanteng Kabupaten Tegal). Journal of Educational Social Studies (JESS) Vo. 1 No. 2. http://journal.unnes.ac.id/sju/index.php/jess. Diakses 27 Mei 2019.

Suryawati \& Maryawati. 2001. Sosiologi. Jakarta: Esis

Umar, Elmia. 2014. Kecerdasan Emosional Pada Peningkatan Hasil Belajar IPS Melalui Belajar Kooperatif di SD Laboratorium UNG. Vol.01. Nomor.02. di akses tanggal: 27 Desember 2017.

Zubaedi. 2011. Desain Pendidikan Karakter. Jakarta: PT Prenada Media Group. 